\title{
On Shao Yong's Method for Observing Things
}

\section{Citation}

Bol, Peter. 2013. On Shao Yong's Method for Observing Things. Monumenta Serica 61:287-299.

\section{Published Version}

http://www.monumenta-serica.de/monumenta-serica/publications/journal/Catolog/VolumeLXI-2013.php

\section{Permanent link}

http://nrs.harvard.edu/urn-3:HUL.InstRepos:17935880

\section{Terms of Use}

This article was downloaded from Harvard University's DASH repository, and is made available under the terms and conditions applicable to Open Access Policy Articles, as set forth at http:// nrs.harvard.edu/urn-3:HUL.InstRepos:dash.current.terms-of-use\#OAP

\section{Share Your Story}

The Harvard community has made this article openly available.

Please share how this access benefits you. Submit a story.

\section{Accessibility}




\title{
On Shao Yong’s Method for Observing Things
}

\author{
Peter K. Bol
}

Charles H. Carswell Professor of East Asian Languages and Civilizations, Harvard University, 2 Divinity Avenue, Cambridge, MA 02138, USA

Title: 論邵雍之觀物法

Abstract: Shao Yong's "Inner Chapters on Observing Things" develops a method for understanding the unity of heaven and man, tracing the decline of civilization from antiquity, and determining how the present can return to the ideal socio-political order of antiquity. Shao's method is based on dividing any topic into fours aspects (for example, four Classics, four seasons, four kinds of rulers, etc.) and generating the systematic relations between these four member sets. Although Shao's method was unusual at the time, the questions he was addressing were shared with mid-eleventh statecraft thinkers.

摘要: 邵雍在《觀物內篇》中發展出了一種獨特的方法, 用來理解天人合一、追溯三代以 後之衰、並確定如何才能復原三代理想的社會政治秩序。邵雍的方法立足於將任意一個主 題劃分為四個種類（例如, 四種經典, 四種季節, 四種統治者, 等等), 並賦予這四個種 類之間以系統性的聯繫。雖然邵雍的方法在當時並非尋常, 可是他所試圖解決的問題卻是 其他十一世紀中葉的政治制度思想家所共同思考的。

Shao's claim to philosophical importance is based on a single book, the Huangji jingshi shu 皇極

經世書 (Supreme Principles for Governing the World) and the various charts and diagrams associated with it, and to much lesser extent his collection of poems, the Jirang ji 擊壤集. Much of his work drew on the Book of Change and the tradition that explored the systems of "image and number" in the Change. Some of the intellectuals Shao came to know in the 1070s, in 
Luoyang, where he had settled in 1048, such as the Cheng brothers and Sima Guang, were also interested in the Change and cosmology, but Shao was independent. He came to be known as articulating the "learning of xian tian 先天 (prior to heaven)," the cosmological process upon which creation is based. Interpreting his work requires a choice of context - should we read this in a mid-eleventh century historical context, in a Daoxue philosophical context, or in the tradition of "image and number" exegesis of the Change? The problem for an historical reading is that the book no longer exists in its original form. This is due in no small part to his son Shao Bowen 郡 伯温 (1057-1134), who actively promoted his father's reputation and probably reworked some of the text, and to other scholars who took up his work and added to it. Recent work on Shao has attempted to make use of these accretions to recreate Shao's life and thought and to take Shao seriously as a philosopher. ${ }^{1}$

A shorter version of this essay is included in Peter K. Bol, "Reconceptualizing the Order of Things in Northern and Southern Sung," in Cambridge History of China (Cambridge: Cambridge University Press, forthcoming). I thank Willard Peterson and Douglas Skonicki for comments on that draft.

${ }^{1}$ Ann Birdwhistell, Transition to Neo-Confucianism: Shao Yung on Knowledge and Symbols of Reality (Stanford: Stanford University Press, 1989); Don J. Wyatt, The Recluse of Loyang: Shao Yung and the Moral Evolution of Early Sung thought (Honolulu: University of Hawaii Press, 1996). On Shao and the Change see Kidder Smith et al., Sung Uses of the I Ching (Princeton: Princeton University Press, 1990). 100-35. Alain Arrault's study of all aspects of Shao Yong's work includes a valuable discussion of the "method tétranomique," the subject of this essay; see Alain Arrault, Shao Yong (1012-1077) : poète et cosmologue (Paris: Collège de France, 2002). 286-303. There is not a unified view of Shao. For example Haiming Wen sees Shao as having an 
Yin Dun, a disciple of the Chengs, once commented that although his contemporaries saw Shao as contributing to Change studies what he basically offered was "learning for ordering the world." "2 This observation corresponds to Shao's title. Shao Bowen's description of the original text refers to a work in twelve chapters devoted to establishing numerical correspondences between cycles of time and human events, between the numbers of yin and yang and music and the myriad things. ${ }^{3}$ The work that we now have that is accepted as being from Shao Yong's own hand is the Guanwu neipian 觀物內篇 (“Inner Chapters on Observing Things"). It is included in the current text of the Huangji jingshi and perhaps corresponds to the original last two chapters, which Shao Bowen described as being about how the book was done. In any case this relatively succinct text is a well-organized and methodologically consistent treatise. Rather than trying to give a synthetic account of Shao's philosophy or contributions to Daoxue, I shall use this work alone as the basis for reaching conclusions about what Shao was trying to accomplish.

"epistemology of the heart-and-mind" (Haiming Wen, "Continuity of Heart-mind and Thingsevents: A Systematic Reconstruction of Neo-Confucian Epistemology," Asian Philosophy 21, no. 3 (2011): 275-6.) whereas Zijiang Ding argues that he is a numerologist and in many respects similar to Pythagoras; see Zijiang Ding, "The Numerical Mysticism of Shao Yong and Pythagoras.," Journal of Chinese Philosophy 32, no. 4 (2005). The recent edition of Shao Yong's works reads the material covered in this essay in a similar way, see Shao Yong 邵雍, Shao Yong $j i$ 邵雍集 (Beijing: Zhonghua shuju, 2010). 1-50.

${ }^{2}$ Cited in Hou Wailu 侯外庐, Qiu Hansheng 邱汉生, and Zhang Qizhi 张岂之, Song Ming li xue $s h i$ 宋明理学史 (Beijing 北京: Renmin chuban she 人民出版社, 1984). 204.

${ }^{3}$ Ibid. 
Shao's "method" involves the use of polarities and four-member sets, which he correlates, multiplies, and integrates. These sets are derived from the bipolarity of heaven-andearth as found in the Change. Shao deploys a limited number of polarities: heaven and earth, the yang 陽 and yin 陰 of heaven, the gang 剛 and rou 柔 (firm and yielding) of earth, dong 動 and $j i n g$ 靜 (active and tranquil), the classes of dong 動 and $z h i$ 植 (moving and growing) things, $t i$ 體 and yong 用 (structure and function), bian 變 and hua 化 (change and transformation), gan 感 and ying 應 (stimulus and response), and ge 革 and yin 因 (change and continuity).

The justification for sets with four members is based on treating the basic pairing of yinyang and gang-rou as cycles with major (rising) and minor (falling) phases. Thus:

\begin{tabular}{|c|c|c|c|}
\hline \multicolumn{2}{|c|}{ Heaven } \\
\hline \multicolumn{2}{|c|}{ Yang } & \multicolumn{2}{c|}{ Yin } \\
\hline tai-yang & shao-yang & tai-yin & shao-yin \\
\hline
\end{tabular}

which has as its parallel:

\begin{tabular}{|l|c|c|c|}
\hline \multicolumn{2}{|c|}{ Earth } \\
\hline \multicolumn{2}{|c|}{ Gang } & \multicolumn{2}{c|}{ Rou } \\
\hline tai-gang & shao-gang & tai-rou & shao-rou \\
\hline
\end{tabular}

out of which Shao generates all creation or the "ten-thousand things." It begins with yang and yin giving rise to the structuring elements of heaven: 


\begin{tabular}{|l|l|l|l|}
\hline tai-yang & tai-yin & shao-yang & shao-yin \\
\hline produces & produces & produces & produces \\
\hline Sun & Moon & Planets & Stars \\
\hline
\end{tabular}

And of earth:

\begin{tabular}{|l|l|l|l|}
\hline tai-rou & tai-gang & shao-rou & shao-gang \\
\hline produces & produces & produces & produces \\
\hline Water & Fire & Earth & Stone \\
\hline
\end{tabular}

These structuring elements respectively make:

\begin{tabular}{|c|c|c|c|}
\hline Sun & Moon & Planets & Stars \\
\hline produces & produces & produces & produces \\
\hline Warmth & Cold & Day & Night \\
\hline
\end{tabular}

and

\begin{tabular}{|c|c|c|c|}
\hline Water & Fire & Earth & Stone \\
\hline produces & produces & produces & produces \\
\hline Rain & Wind & Dew & Thunder \\
\hline
\end{tabular}


The interaction of the first set of products "realizes all the changes of heaven" and the interaction of the second set "realizes all the transformations of earth." The products (warmth, etc.) of the heavenly structuring elements (sun, etc.) in turn affect four aspects of the make-up of a thing (nature, etc.):

\begin{tabular}{|c|c|c|c|}
\hline Warmth & Cold & Day & Night \\
\hline changes & changes & changes & changes \\
\hline Nature & Emotion & Form & Structure \\
\hline
\end{tabular}

The products (rain, etc.) of the earthly structuring elements (water, etc.) in turn affect four kinds of living things (walkers, etc.).

\begin{tabular}{|c|c|c|c|}
\hline Rain & Wind & Dew & Thunder \\
\hline transforms & transforms & transforms & transforms \\
\hline Walkers & Flyers & Plants & Trees \\
\hline
\end{tabular}

Each set of four interact among themselves and thereby all possible stimuli and responses of the two grand classes of things ("moving" and "growing") are realized.

Shao can now establish the set of possible interactions among these parallel elements of heaven and of earth. To discover this he has the elements interact with each other, giving each result in narrative form. The point is not that they refer things that exist in the phenomenal world but that the possibilities for the phenomenal world are being generated systematically, by multiplying, so to speak, members of each set against each other. I will take this in two steps. First, Shao's rules allow him to join rows to columns and columns to rows. Thus Nature 
subdivides into four (Walkers of Nature, Flyers of Nature, etc.) but Walkers also divide into four (Nature of Walkers, Emotion of Walkers, etc.).

\begin{tabular}{|c|c|c|c|c|}
\hline & Walkers & Flyers & Plants & Trees \\
\hline \multirow[t]{2}{*}{ Nature } & $\begin{array}{l}\text { Walkers of } \\
\text { nature }\end{array}$ & $\ldots$ & $\ldots$ & $\cdots$ \\
\hline & $\begin{array}{l}\text { Nature of } \\
\text { walkers }\end{array}$ & ... & $\ldots$ & $\ldots$ \\
\hline \multirow[t]{2}{*}{ Emotion } & $\begin{array}{l}\text { Walkers of } \\
\text { emotion }\end{array}$ & $\begin{array}{l}\text { Flyers of } \\
\text { emotion }\end{array}$ & $\ldots$ & $\ldots$ \\
\hline & $\begin{array}{l}\text { Emotion of } \\
\text { walkers }\end{array}$ & $\begin{array}{l}\text { Emotion of } \\
\text { flyers }\end{array}$ & $\ldots$ & $\ldots$ \\
\hline \multirow[b]{2}{*}{ Form } & Walkers of form & $\ldots$ & Plants of Form & \\
\hline & Form of walkers & $\ldots$ & Form of plants & \\
\hline \multirow[t]{2}{*}{ Structure } & $\begin{array}{l}\text { Walkers of } \\
\text { structure }\end{array}$ & $\ldots$ & $\cdots$ & $\begin{array}{l}\text { Trees of } \\
\text { structure }\end{array}$ \\
\hline & $\begin{array}{l}\text { Structure of } \\
\text { walkers }\end{array}$ & $\ldots$ & $\ldots$ & Structure of trees \\
\hline
\end{tabular}

Second, he uses them to identify the mode of production or the mode of interaction that produces a certain result. In this case he has each of the earthly elements being "changed when stimulated by" 


\begin{tabular}{|l|l|l|l|}
\hline Warmth & Cold & Day & Night \\
\hline
\end{tabular}

so that "Walkers that change when stimulated by warmth are the walkers of nature" zou gan shu er bian zhe xing zhi zou ye 走感署而變者性之走也, “Walkers that change when stimulated by cold are the walkers of emotion” zou gan han er bian zhe qing zhi zou ye 走感寒而變者清之走 也, etc. The heavenly elements for their part are "transformed in response to"

\begin{tabular}{|c|c|c|c|}
\hline Rain & Wind & Dew & Thunder \\
\hline
\end{tabular}

so that "Nature that transforms in response to rain is the nature of walkers," "Emotion that is transformed in response to wind is emotion of flyers," and so on.

The operations Shao is performing are mathematical but Shao rarely uses numbers; the exception is the tenth section which uses verbal expressions for the four cycles of time but defines their numerical values of $1,12,30$. A cumulative multiplication table represents what Shao has in mind when he gives the numbers of the four. He thus has sixteen items, each of which can be named as if multiplied by the other (from yuan of yuan to shi of shi) but which in fact result from the cumulative multiplication along the column or row (e.g. the number of shi of yuan is $1 \times 12 \times 30 \times 12=4320)$.

\begin{tabular}{|c|c|c|c|c|}
\hline Yuan & Hui & Yun & Shi \\
Day & Month & Year & Era \\
1 & $1 \times 12$ & $1 \times 12 \times 30$ & $1 \times 12 \times 30 \times 460$ \\
\hline
\end{tabular}




\begin{tabular}{|l|l|l|l|l|}
\hline $\begin{array}{l}\text { Yuan } \\
1\end{array}$ & $\begin{array}{l}\text { Yuan of } \\
\text { yuan } \\
1 \times 1\end{array}$ & $12 \times 1$ & $360 \times 1$ & $4320 \mathrm{x} 1$ \\
\hline Hui & $1 \times 12$ & $12 \times 12=144$ & $360 \times 12=4320$ & $4320 \times 12=51840$ \\
12 & & & & \\
\hline Yun & $1 \times 360$ & $12 \times 360=4320$ & $360 \times 360=129600$ & $4320 \times 360=1555200$ \\
\hline Shi & $1 \times 4320$ & $12 \times 4320=51840$ & $360 \times 4320=1555200$ & Shi of shi \\
12 & & & & $4320 \times 4320=18662400$ \\
\hline
\end{tabular}

In this case fieldXrow and rowXfield are equivalent. But as we have already seen the case of Walkers and Nature, in verbal expressions fieldXrow and rowXfield are distinct and a four-byfour grid gives 32 items.

I shall not elaborate on Shao's uses of these sets, except to note their existence; we shall see some in more detail.

\begin{tabular}{|l|l|l|l|l|}
\hline Looks & Sound & Qi & Taste & Heavenly capacities \\
\hline Ear & Eye & Mouth & Nose & Earthly capacities \\
\hline Spring & Summer & Fall & Winter & Heaven's seasons \\
\hline Birth & Growth & Harvest & Storage & Life cycle \\
\hline Change & Documents & Odes & Spring and Autumn & Sage's constants or \\
& & & Annals & Classics \\
\hline Transforming & Teaching & Exhorting & Commanding & Ways of ruling \\
\hline
\end{tabular}




\begin{tabular}{|l|l|l|l|l|}
\hline Way & Virtue & Achievement & Force & Means with which to \\
transform others
\end{tabular}

Shao uses all these sets in various combinations. The logic of these combinations may be neither necessary nor obvious, but Shao uses them to link together what is of heaven, earth, and man and to define what from Shao's perspective is possible and necessary.

Granting that Shao has a method, but to what end? There are various ways to contextualize and interpret the "Inner Chapters on Observing Things." Here, drawing on my general acquaintance with mid-eleventh century intellectual culture, I will read the twelve section of the piece as answers to a related series of questions, beginning from the problem of the status of the human being and ending with the possibility of transforming the world through government. These were also problems for the reform thinkers of his day. What sets Shao apart is his conviction that answers can be found by understanding the systematic processes of heaven- 
and-earth. This summary will ignore most of the elaborate mechanical operations Shao performs with his quadripartite sets in support of his assertions. ${ }^{4}$

1. What makes the human being different from all the other myriad things, given that in fact man is one of the things brought into being by heaven-and-earth? In contrast to all the other things, each of which has been apportioned some part of the set of possible allotments and abilities, man is capable of being stimulated by everything and responsive to everything. He is without limits while all other things are limited.

2. What makes the sage different from other men, given that men are also things and sages are also men? Just as man is able to employ at will the four senses to perceive everything and is the most perfect of things, the sage is the most perfect of men and is able to perceive everything that all humanity perceives. With one mind he observes the myriad minds; with one body, with one thing, with one age he observes all bodies, things, and ages. And thus the sage can speak and act for heaven.

The sage is thus firmly embedded within heaven-and-earth and his abilities are simply the perfection of abilities that all men have and that the myriad things (when taken as a whole) possess. If there is an alternative heaven-and-earth and myriad things, Shao asserts, the sage would not be able to know about it and for him to speak of such would be ungrounded. To act on the basis of ungrounded claims would be wrong.

\footnotetext{
${ }^{4}$ Shao Yong 邵雍, Huang ji jing shi shu 皇極經世書, Sibu beiyao ed. (Taibei: Taiwan zhonghua shuju, (rpt. 1969)). 5.1a-6.27b. The summary corresponds to the twelve numbered sections of the text.
} 
Presumably this attacks Buddhism and Daoism, both of which posited realms of existence beyond the single realm of heaven-and-earth as evident to direct perception.

3. Why is the sage able to fully realize the potentials of humanity? Because he understands that humanity is the summa of heaven-and-earth and the myriad things. The sage operates relative to man just as heaven operates relative to things. Heaven has the four seasons to bring things to completion; the sage has the four classics/constants to bring things to completion, as in "Spring is the storehouse for giving birth to things...The Change is the storehouse for giving birth to the populace."

\begin{tabular}{|l|l|l|l|l|}
\hline Birth & Growth & Harvest & Storage & Life cycle \\
\hline Change & Documents & Odes & Spring and Autumn Annals & Sage's constants or Classics \\
\hline
\end{tabular}

4. What are the ways in which the people can be brought to completion? There are sixteen permutations each of the functions of the seasons and of the classics:

\begin{tabular}{|l|l|l|l|l|}
\hline & Change & Documents & Songs & Annals \\
\hline
\end{tabular}




\begin{tabular}{|c|c|c|c|c|}
\hline Change & $\begin{array}{l}\text { Changing } \\
\text { the Change } \\
\text { [or: the Change in } \\
\text { the Change] }\end{array}$ & $\begin{array}{l}\text { Documenting the } \\
\text { Change }\end{array}$ & $\begin{array}{l}\text { Singing the } \\
\text { Change }\end{array}$ & \\
\hline Documents & $\begin{array}{l}\text { Changing } \\
\text { the Documents }\end{array}$ & $\begin{array}{l}\text { Documenting the } \\
\text { Documents }\end{array}$ & & \\
\hline Songs & $\begin{array}{l}\text { Changing } \\
\text { the Songs }\end{array}$ & $\begin{array}{l}\text { Documenting the } \\
\text { Songs }\end{array}$ & & \\
\hline Annals & $\begin{array}{l}\text { Changing } \\
\text { the Annals }\end{array}$ & $\begin{array}{l}\text { Documenting the } \\
\text { Annals }\end{array}$ & & $\begin{array}{l}\text { Annaling the } \\
\text { Annals }\end{array}$ \\
\hline
\end{tabular}

\begin{tabular}{|l|l|l|l|l|}
\hline & Birth & Growth & Harvest & Storage \\
\hline Birth & Birthing & $\ldots$ & $\ldots$ & $\ldots$ \\
\hline Growth & $\ldots$ & & & \\
\hline Harvest & $\ldots$ & $\ldots$ & $\ldots$ & $\ldots$ \\
\hline Storage & $\ldots$ & $\ldots$ & $\ldots$ & Storing \\
& & & & \\
\hline
\end{tabular}

These correspond to each other (from Change of Change as birthing birth to Annaling the Annals as storing storage). These two sets of sixteen correspond to the following set of sixteen, where each row are four functions (yong) of the one of the Four Classics 


\begin{tabular}{|c|c|c|c|c|}
\hline Idea & Words & Image & Number & $\begin{array}{l}\text { Functioning of the } \\
\text { Change }\end{array}$ \\
\hline Benevolence & Ritual & Righteousness & Knowledge & $\begin{array}{l}\text { Functioning of the } \\
\text { Documents }\end{array}$ \\
\hline Nature & Emotions & Form & Structure & $\begin{array}{l}\text { Functioning of the } \\
\text { Odes }\end{array}$ \\
\hline Sageliness & Worthiness & Talent & Technique & $\begin{array}{l}\text { Functioning of the } \\
\text { Annals }\end{array}$ \\
\hline
\end{tabular}

So "one who is birthing birth [and thus Changing the Change] cultivates idea" and one who is storing storage [and thus Annaling the Annals] cultivates technique." That set of sixteen corresponds to a further set of sixteen historical rulers or groups of rulers:

\begin{tabular}{|l|l|l|l|l|}
\hline Three & Five & Three & Five & Structuring element of the \\
monarchs & emperors & kings & hegemons & Change \\
\hline Shun & Yu of Xia & $\begin{array}{l}\text { Tang of } \\
\text { Shang }\end{array}$ & Fa of Zhou & $\begin{array}{l}\text { Structuring element of the } \\
\text { Documents }\end{array}$ \\
\hline King Wen & King Wu & $\begin{array}{l}\text { Duke of } \\
\text { Zhou }\end{array}$ & Duke Shao & $\begin{array}{l}\text { Structuring element of the } \\
\text { Odes }\end{array}$ \\
\hline Mu of Qin & Wen of Jin & Huan of Qi & Zhuang of & Structuring element of the \\
& & & Chu & Annals \\
\hline
\end{tabular}


so that the one who cultivates idea is acting as one of the historical Three Monarchs and he who cultivates technique is acting as the historical Zhuang of Chu. "The functioning," Shao writes, "is the mind. The structuring elements are the traces. Between the mind and the traces there is situational judgment (quan 權). This is matter for sages."

The four kinds of rulers (row 1 above)

\begin{tabular}{|l|l|l|l|}
\hline Three monarchs & Five emperors & Three kings & Five hegemons \\
\hline
\end{tabular}

ruled others in different ways, by:

\begin{tabular}{|l|l|l|l|}
\hline Transforming & Teaching & Exhorting & Commanding \\
\hline
\end{tabular}

in each case they were doing so using different means:

\begin{tabular}{|l|l|l|l|}
\hline Way & Virtue & Achievement & Force \\
\hline
\end{tabular}

and were characterized by their:

\begin{tabular}{|l|l|l|l|}
\hline Nature & Emotions & Form & Structure \\
\hline
\end{tabular}

For example: 
The Three Monarchs shared the same Idea but Transformed [people] differently.

"To do this they must have relied on the Way. When one transforms people with the Way the people also accept their rule according to the Way. Therefore [this method] values Spontaneity."

The Five Emperors shared the same Ritual but Taught [people] differently.

"To do this they must have relied on Virtue. When one Teaches people with Ritual the people also accept their rule according to Virtue. Therefore [this method] values Giving Way.

The Three Kings shared the same Form but Exhorted [people] differently.

"To do this they must have relied on Achievement. When one Exhorts the people with Achievement the people also accept their rule according to Achievement. Therefore [this method] values Government.

The Five Hegemons shared the same Techniques but Led [people] differently. "To do this they must have relied on Force. When one Leads the people with Force the people also accept their rule according to Force. Therefore [this method] values Competition."

Thus:

\begin{tabular}{|l|l|l|l|}
\hline Three & Five emperors & Three kings & Five hegemons \\
\hline
\end{tabular}




\begin{tabular}{|l|l|l|l|}
\hline monarchs & & & \\
\hline share the & share the & share the & share the \\
\hline Idea & same: & Imame: \\
\hline Benevolence & Ritual & Righteousness & Knowledge \\
\hline Nature & Emotions & Form & Structure \\
\hline Sageliness & Worthiness & Talent & Technique \\
\hline but & but & but & but \\
\hline Transform & Teach & differently: & differently: \\
\hline through: & through: & through: & through: \\
\hline Way & Virtue & Achievement & Force \\
\hline
\end{tabular}

This is a hierarchic taxonomy of political values, as Shao explains: government in the style of the Three Monarchs values spontaneity (自然ziran) and not forcing things. The style of the Five Emperors values giving way to others and not trying to hold onto things. Government in the manner of Three Kings values governing, correct others who bring harm and thus benefitting the populace. And the style of the Five Hegemons values competition yet in doing so defend the dynasty and civilization. This is also a record of the decline of the polity, but at the same time, as we shall see, it marks the course by which it can be restored. Moreover, knowing that these correlations exist, the sage, like heaven, is able to exercise the power to go against the current norm and change the situation (quan) just as heaven brings about changes in the seasons. The 
ultimate standard of value by which the exercise of such power must be measured, Shao asserts, is whether or not it "gives life to the populace."

5. Why is the way of the sage Confucius better than any other approach to rule? Because he understood, having seen all these variations and permutations, that a Monarch could use the Way, Virtue, Achievement, and Force to transform others. (In general, the upper left hand cell on any table can include all others within it, it is inclusive rather than exclusive). He understood that the times for different styles of rule come and go and that the Four Classics were subject to continuity and change. Indeed, depending on how the mandate to rule was obtained the resulting polity lasted between one and one thousand generations, but Confucius's way will last for a myriad generations, for he saw that everlasting continuity and increase was a matter of according with the times.

6. Why was it possible for Confucius to see this Way? Because with the material of the Four Classics he could see all the variations and developments; he lived in the time the Hegemons, when the polity had reached its lowest level. Confucius did not hold land and govern, his estate was time immemorial. No one took advantage of what he had figured out and those who came close, like the state Qin, sacrificed the opportunity because they did not care about life.

7. What should the ruler today do? The sage kings did not all do the same thing; time comes and goes and affairs continue and change, but ultimately the state of society 
depends upon what the ruler values. The most important way he shows this is through whom he chooses as his ministers. He cannot get rid of self-interested people but he can choose not to employ him. He should know from the Five Hegemons that when words and profit are valued over deeds and righteousness the world is descending into disorder, thus like the Three Kings he should give precedence to those who value deeds. But most important of all he should, in the manner of Confucius, value those who “fathomed it fully in their minds" (jin zhi yu xin 盡之於心 ).

8. Will the ruler be able to do this? Yes, if he opens the "path of life" (sheng lu 生路) he will make it possible for others to give their all.

9. Can the ruler today change the state of the polity? Yes, in three stages he can move society from the state of the Hegemon to the state of the Monarch, one stage per generation (in a four by four grid one can arrive at the upper-left cell in at most three steps from any position in the grid because one can move laterally). Heaven-and-earth and human and things are different yet they are all unified by the Way, even if the Way is only manifest through affairs it is the path that people can follow eternally. But, Shao notes, some ask how one can know the Way that those in power follow is the right one? Will not any group that is ascendant make this claim? The Way is not relative, Shao responds, it is correct or not. It demands that each person fulfill the duties of his or her position and that the moral relationship between positions be maintained. 
10. How can we know that change is possible? Do not the cycles of time in fact determine what is possible, given that since the Zhou dynasty history has seen an alteration between the rule of King and Hegemon? Shao runs through a series of correspondences and permutations from which he draws the conclusion that in fact change is possible, that within three stages the populace can be transformed and customs unified. The key to his argument is that there are cycles and variations within cycles and variations. Two tables make this point. The first shows that there are sixteen levels of rulership

\begin{tabular}{|l|l|l|l|l|}
\hline & Monarch & Emperor & King & Hegemon \\
\hline Monarch & Monarch- & $\ldots$ & $\ldots$ & $\ldots$ \\
\hline Emperor & $\ldots$ & Emperor- & $\ldots$ & \\
\hline King & $\ldots$ & emperor & & $\ldots$ \\
\hline Hegemon & $\ldots$ & $\ldots$ & King-king & $\ldots$ \\
\hline
\end{tabular}

Which maps onto 16 means and ends:

\begin{tabular}{|l|l|l|l|l|}
\hline & Way & Virtue & Achievement & Force \\
\hline Way & $\begin{array}{l}\text { w/ Way practice } \\
\text { affairs of the Way }\end{array}$ & w/ Way practice & w/ Way practice & w/ Way practice \\
& & affairs of the & affairs of the \\
\hline
\end{tabular}




\begin{tabular}{|c|c|c|c|c|}
\hline & & Virtue & Achievement & Force \\
\hline Virtue & $\begin{array}{l}\text { w/ Virtue practice } \\
\text { affairs of the Way }\end{array}$ & $\begin{array}{l}\text { w/ Virtue practice } \\
\text { affairs of Virtue }\end{array}$ & $\begin{array}{l}\text { w/ Virtue practice } \\
\text { affairs of the } \\
\text { Achievement }\end{array}$ & $\begin{array}{l}\text { w/ Virtue practice } \\
\text { affairs of Force }\end{array}$ \\
\hline Achievement & $\begin{array}{l}\text { w/ Achievement } \\
\text { practice affairs of } \\
\text { the Way }\end{array}$ & $\begin{array}{l}\text { w/ Achievement } \\
\text { practice affairs of } \\
\text { Virtue }\end{array}$ & $\begin{array}{l}\text { w/ Achievement } \\
\text { practice affairs of } \\
\text { Achievement }\end{array}$ & $\begin{array}{l}\text { w/ Achievement } \\
\text { practice affairs of } \\
\text { Force }\end{array}$ \\
\hline Force & $\begin{array}{l}\text { w/ Force practice } \\
\text { affairs of the Way }\end{array}$ & $\begin{array}{l}\text { w/ Force practice } \\
\text { affairs of Virtue }\end{array}$ & $\begin{array}{l}\text { w/ Force practice } \\
\text { affairs of } \\
\text { Achievement }\end{array}$ & $\begin{array}{l}\text { w/ Force practice } \\
\text { affairs of Force }\end{array}$ \\
\hline
\end{tabular}

The hegemon-hegemon who uses force to practice the affairs of force can become a kingking by using achievement to practice the affairs of achievement, and then virtue, and then the Way. But he has many other paths as well. He can improve.

11. What does it mean to be a human? With another series of sets, correspondences, and permutations Shao returns to the theme of the first section. Heaven and earth and the myriad things all receive a particular allotment of yin and yang, gang and rou. But man is greater than all, for man is that in which "heaven-and-earth and the myriad things are complete.” In him heaven and earth are fully integrated. By Shao's calculation the "comprehensive number" of all creation is $289,816,576$ !

12. What kind of humans should we become? Shao runs through another series of tables, beginning with the major categories of heavenly and earthly things, to argue for an inherent hierarchy of things (the sun-sun things are flyer-flyers) thus to show that the 
populace of the monarch-monarch are literati-literati (shi-shi). And just as flyer-flyers are nature-nature (xing-xing) so are the shi-shi people benevolent-benevolent. His next demonstration begins with a $4 \times 4$ table of $1,10,100,1000$. The point here is to show that the highest order things are whole while the lower order things are ever smaller parts of the whole: the flyer-flyer things are one of one (unity of unity), but plant-plant things are 1000-1000 (one-thousandth of one-thousandth), which means that a $1 / 1$ flyer is equal to $1,000,000$ (but a $1 / 10$ only to 100,000 ). So too then are the $1 / 1$ shi equal to $1,000,000$ others while the $1000-1000$ merchant is equal to a single person. So the greatest thing and the greatest person can only be the $1 / 1$ kind. We should become this kind of shi and have the broadest and most inclusive view, this is to be "perfectly marvelous (shen 神), perfectly sage." And we can learn to do that if we learn to "observe things" not with the eyes, not even with the mind, but with coherence ( $l i$ 理) and thus have true knowledge. The key to this is to practice "reverse observation" which means to observe things in terms of each other, not from the perspective of the self (and one's own interests). So I know, Shao concludes, that I am a man like others and that we are all "things," and thus I can use the eyes, ears, mouth, and mind of all under heaven to see, hear, speak, and plan. Then what I know will be complete, this is what it means to be "perfectly marvelous (shen), perfectly sage."

Shao's "Inner Chapters on Observing Things" is both an illustration of "using things to observe things" and a treatise that reaches definitive conclusions with that method. It is a mechanical system, yet if it pigeon-holes almost everything it also supposes that it is possible to change 
states. Indeed, it tells the reader exactly what is required in in every possible state. Those readers are the literati and it is the literati as the group in society that has transformative power according to Shao's system. Moreover, it is an example of a startling possibility: that the discovery of a coherent system makes it possible to discard tradition - such as the Five Classics and Five Phases. But it is also an attempt to envision the material world as complete and sufficient, a world that contains within itself the guides to its own self-transformation. This world is the physical concrete world of heaven-and-earth and, in contrast to the reform thinkers, Shao sees the Change as evidence that Confucius used an understanding of heaven-and-earth process to sort out human history through the Four Classics. ${ }^{5}$ Shao is generally seen as a numerologist, but in his own scheme of things in this text "number" (shu 數) as such is not fundamental. A better understanding of the mathematical quality of the "Inner Chapters" would be to say they illustrate an interest in the "generation of systematic relationships between members of finite sets."

\footnotetext{
${ }^{5}$ If we accept received tradition there are only four Classics that Confucius could have edited.
} 
Arrault, Alain. Shao Yong (1012-1077) : Poète Et Cosmologue. Paris: Collège de France, 2002. Birdwhistell, Ann. Transition to Neo-Confucianism: Shao Yung on Knowledge and Symbols of Reality. Stanford: Stanford University Press, 1989.

Bol, Peter K. "Reconceptualizing the Order of Things in Northern and Southern Sung." In Cambridge History of China. Cambridge: Cambridge University Press, forthcoming.

Ding, Zijiang. "The Numerical Mysticism of Shao Yong and Pythagoras.". Journal of Chinese Philosophy 32, no. 4 (2005): 615-32.

Hou Wailu 侯外庐, Qiu Hansheng 邱汉生, and Zhang Qizhi 张岂之. Song Ming Li Xue Shi 宋 明理学史. Beijing 北京: Renmin chuban she 人民出版社, 1984.

Shao Yong 邵雍. Huang Ji Jing Shi Shu 皇極經世書. Sibu beiyao ed. Taibei: Taiwan zhonghua shuju, (rpt. 1969).

—. Shao Yong $J i$ 邵雍集. Beijing: Zhonghua shuju, 2010.

Smith, Kidder, Peter Bol, Joseph Adler, and Don Wyatt. Sung Uses of the I Ching. Princeton: Princeton University Press, 1990.

Wen, Haiming. "Continuity of Heart-Mind and Things-Events: A Systematic Reconstruction of Neo-Confucian Epistemology." Asian Philosophy 21, no. 3 (2011): 269-90.

Wyatt, Don J. The Recluse of Loyang: Shao Yung and the Moral Evolution of Early Sung Thought. Honolulu: University of Hawaii Press, 1996. 